F. Reprod. Fert. (1967) 13, 321-327

\title{
THE RESPONSE OF FEMALE MICE TO REPEATED INJECTIONS OF HUMAN CHORIONIC GONADOTROPHIN
}

\author{
R. B. LAND* AND ANNE MaLAREN \\ A.R.C. Unit of Animal Genetics, Institute of Animal Genetics, Edinburgh
}

(Received 22nd September 1966)

\begin{abstract}
Summary. A study was made of the response of female mice to 1, 6, 12, 18 and 24 days of treatment with 2 i.u. of human chorionic gonadotrophin daily. It was found that: (1) ovulation in response to the exogenous hormone ceased between the 6 th and the 12th day; (2) between the 6 th and the 18th day, the mice resumed normal oestrous cycles; (3) the quality of eggs shed at natural oestrus during and after treatment was unimpaired, as judged by pregnancy examinations; (4) the ability of the females to maintain pregnancy after treatment was similarly unimpaired; and (5) during the period in which the females were responding to the exogenous hormone, they did not display the 'Whitten effect'. The results indicated that immunity had arisen to human chorionic gonadotrophin, but not to endogenous luteinizing hormone.
\end{abstract}

\section{INTRODUCTION}

The ovarian response of mice to continuous and semi-continuous treatment with pregnant mare's serum (PMs) followed by human chorionic gonadotrophin (HCG) was studied by Lin \& Bailey (1965). The results of this study confirmed the earlier work of Edwards \& Fowler (1960) on the mouse, and Willett, Buckner \& McShan (1953) on the cow, that the magnitude of the ovulatory response is inversely correlated with the duration of gonadotrophin treatment, and further showed that the rate of decrease in the number of eggs shed varies between strains. Their results are compatible with the conclusion of Thompson (1941) that the refractoriness is due to the build-up of an immunity to the exogenous hormones. Land (1967) observed that although there was a significant decline in the number of eggs shed in response to daily treatment with HGG alone, the number of eggs shed after 1 to 6 days of treatment was still similar to the number shed at natural oestrus.

In order to study this phenomenon further we decided to examine not only the number of eggs shed in response to longer periods of daily HCG treatment, but also the number shed at natural oestrus both during and after treatment. In order to investigate the 'quality' of the eggs shed, pregnancies resulting from mating during and after treatment were also examined.

* Present address: A.R.C. Animal Breeding Research Organization, Edinburgh 9. 


\section{MATERIALS AND METHODS}

Mice from the outbred $Q$ stock (maintained at the Institute of Animal Genetics, Edinburgh) were used. All females were 8 to 10 weeks of age at the start of the experiment, and had had no contact with males since 3 weeks of age. All females were regrouped into fresh cages at the start of the experiment.

Treatment consisted of the intraperitoneal injection of $0.1 \mathrm{ml}$ of a $20 \mathrm{i} . \mathrm{u} . / \mathrm{ml}$ solution of HCG (Pregnyl; Organon Ltd) at about 12.00 hours. Fresh solutions of HCG were prepared on alternate days.

Eggs were counted by killing the female between 09.00 hours and 12.00 hours and searching the oviducts. Single-celled eggs embedded in the cumulus mass were regarded as having been shed during the previous night, and termed 'fresh eggs', while those not embedded in cumulus, as well as fragmented eggs caught up in the cumulus mass, were regarded as having come from earlier ovulations and termed 'old eggs'. Only those females which contained 'fresh' eggs were regarded as having ovulated during the previous night.

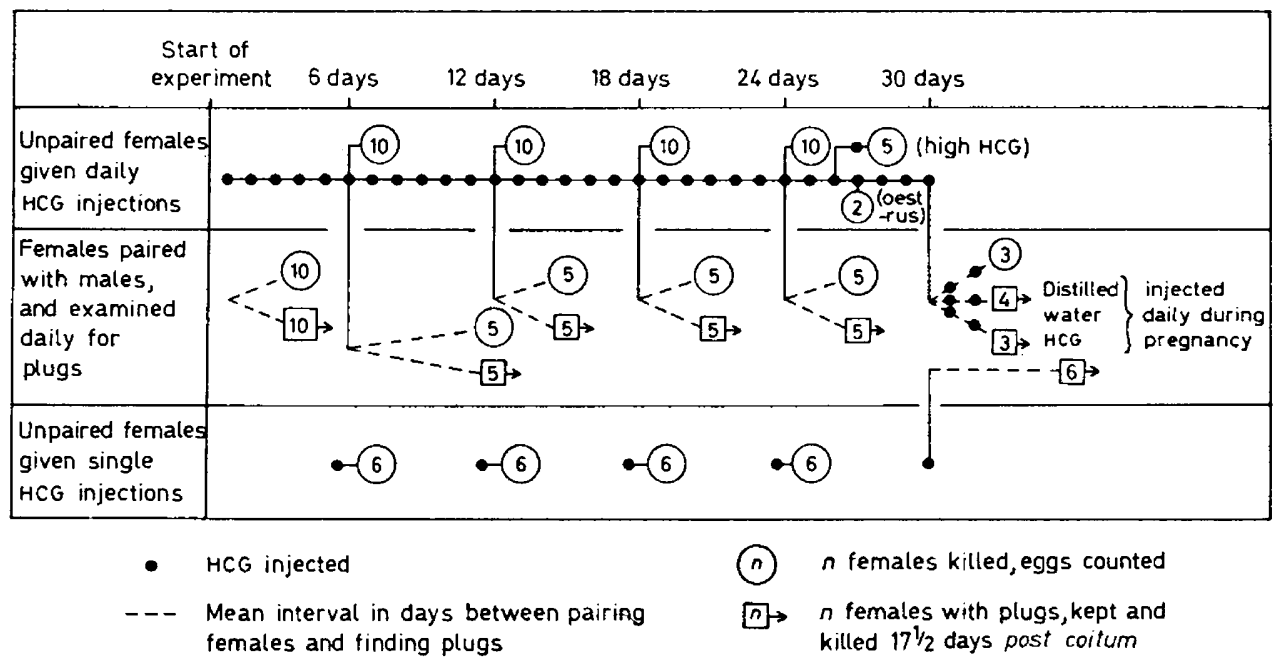

Text-Fig. 1. The plan of the experiment.

The numbers of live and dead embryos were recorded $17 \frac{1}{2}$ days post coitum (i.e. the 18th day of pregnancy).

Of the total of 150 females which were used, 100 (experimental) females received daily injections of HCG (2 i.u.). After 6, 12, 18 and 24 injections, ten of these were killed for egg counts and ten paired with males and examined daily for copulation plugs. They received no further HCG injections after pairing. On the day that the presence of a plug indicated that mating had occurred, five of the paired females were killed for egg counts and the remainder were kept for embryo counts.

After 24 days of HCG injections, during which two of the females died, vaginal smears were taken from the remaining eighteen females for 3 days consecutively. Two females in oestrus were then killed and the number of eggs shed was recorded. A further five were killed, and their oviducts searched for eggs, the 
morning after receiving an HCG injection of 2 to 16 i.u. The remaining eleven females were paired with males while continuing to receive HCG injections daily. One failed to show a plug during a 3-week period and was discarded. Three were killed on the morning that a plug was found, and the number of eggs shed was recorded. Seven were killed for embryo counts, having received daily injections of HCG (three females) and distilled water (four females) during pregnancy.

At the beginning of the experiment twenty untreated females were paired with males, and examined daily for plugs. Ten were killed on the morning that a plug was found, and the number of eggs shed recorded; ten were killed $17 \frac{1}{2}$ days post coitum, and the uterine contents examined and recorded.

Thirty (control) females received single injections of 2 i.u. HCG. To allow for the possibility of variation between successive batches of hormone, six of these females were treated on the 6 th, six on the 12 th, six on the 18th and six on the 24th day of the experiment; they were killed the following morning and the number of eggs shed was recorded. The remaining six were treated on the 30th day of the experiment, paired with males, examined daily for plugs, killed $17 \frac{1}{2}$ days post coitum and the uterine contents examined and recorded.

The plan of the experiment is summarized in Text-fig. 1 .

\section{RESULTS}

Number of eggs shed in response to $H C G$

The results are shown in Table 1 . As there were no significant differences between the number of eggs shed by the four groups of control females, the

\section{TABLE 1}

THE RESPONSE OF ADULT FEMALE MIGE TO REPEATED OR SINGLE INJECTIONS OF 2 i.u. HGG

\begin{tabular}{|c|c|c|c|c|c|}
\hline & $\begin{array}{l}\text { Days from } \\
\text { the start } \\
\text { of the } \\
\text { experiment }\end{array}$ & $\begin{array}{l}\text { No. of } \\
\text { females } \\
\text { examined }\end{array}$ & $\begin{array}{c}\text { No. of } \\
\text { females } \\
\text { with 'fresh' } \\
\text { eggs }\end{array}$ & $\begin{array}{l}\text { Mean No. of } \\
\text { normal eggsl } \\
\text { female which } \\
\quad \text { ovulated } \\
\quad \pm S . E .\end{array}$ & $\begin{array}{c}\text { No. of } \\
\text { females } \\
\text { with 'old' } \\
\text { eggs }\end{array}$ \\
\hline $\begin{array}{l}\text { Experimental females } \\
\text { (HGG injected daily) }\end{array}$ & $\begin{array}{r}6 \\
12 \\
18 \\
24\end{array}$ & $\begin{array}{l}10 \\
10 \\
10 \\
10\end{array}$ & $\begin{array}{r}10 \\
0 \\
1 \\
3\end{array}$ & $\begin{array}{c}8 \cdot 2 \pm 1 \cdot 8 \\
- \\
12 \cdot 0 \\
10 \cdot 3 \pm 0.9\end{array}$ & $\begin{array}{r}10 \\
9 \\
7 \\
5\end{array}$ \\
\hline $\begin{array}{l}\text { Control females } \\
\text { (single injections } \\
\text { of } \mathrm{HCG} \text { ) }\end{array}$ & $\begin{array}{r}6 \\
12 \\
18 \\
24\end{array}$ & $\begin{array}{l}6 \\
6 \\
6 \\
6\end{array}$ & $\begin{array}{l}6 \\
6 \\
6 \\
6\end{array}$ & $\begin{array}{r}12.7 \pm 1.6 \\
12.5 \pm 1.6 \\
14.2 \pm 1.6 \\
8.5 \pm 1.6\end{array}$ & $\begin{array}{l}0 \\
0 \\
1 \\
1\end{array}$ \\
\hline
\end{tabular}

Standard errors in Tables 1, 2 and 3 were obtained from the within-groups variance.

groups were combined. After 6 successive days of HCG treatment, all the experimental females ovulated, though the number of eggs shed was slightly below the mean level of the combined control females which had received only one injection of HGG $(P<0.05)$. 'Fresh' eggs in cumulus were found in none of the ten experimental females examined after 12 days, in one of the ten examined after 18 days, and in three of the ten examined after 24 days. The 
number of eggs in the four females which ovulated after eighteen and twentyfour HCG injections was similar to the control level. The ovaries have not yet been examined histologically, but those of the 12-day group appeared to have the highest density of corpora lutea. We conclude that after twelve or more successive daily injections of HGG, the capacity of females to respond by shedding eggs is drastically reduced. When ovulation does occur, however, the number of eggs shed is not reduced.

The 'old' eggs, which were so characteristic a feature of the experimental females, varied in number from 2 to $60 / \mathrm{female}$, and in type from intact singlecelled eggs not included in the cumulus mass to very degenerate forms consisting of an almost empty zona pellucida. No 'old' eggs were seen in the four females which had ovulated in the 18-day and 24-day groups.

TABLE 2

THE MEAN NUMBER OF EGGS SHED AT NATURAL OESTRUS BY FEMALES WHICH HAD RECEIVED VARYING NUMBERS OF HGG INJECTIONS BEFORE PAIRING WITH MALES. COPULATION PLUGS WERE FOUND IN ALL THE FEMALES.

\begin{tabular}{c|c|c|c|c}
\hline $\begin{array}{c}\text { No. of HCG } \\
\text { injections }\end{array}$ & $\begin{array}{c}\text { No. of females } \\
\text { paired }\end{array}$ & $\begin{array}{c}\text { No. which } \\
\text { ovulated }\end{array}$ & $\begin{array}{c}\text { Mean No. of } \\
\text { eggs/female which } \\
\text { ovulated } \pm \text { S.E. }\end{array}$ & $\begin{array}{c}\text { No. of females } \\
\text { with 'old' } \\
\text { eggs }\end{array}$ \\
\hline 0 & 10 & 9 & $13 \cdot 0 \pm 0.9$ & 0 \\
6 & 5 & 5 & $14 \cdot 2 \pm 1 \cdot 3$ & 1 \\
12 & 5 & 4 & $13 \cdot 8 \pm 1.4$ & 4 \\
18 & 5 & 5 & $11 \cdot 8 \pm 1 \cdot 3$ & 2 \\
24 & 5 & 5 & $11 \cdot 4 \pm 1 \cdot 3$ & 0 \\
\hline
\end{tabular}

TABLE 3

THE MEAN NUMBER OF LIVE EMBRYOS AND TOTAL IMPLANTATIONS IN FEMALES MATED AT NATURAL OESTRUS AFTER A VARYING NUMBER OF HCG INJECTIONS. COPULATION PLUGS WERE FOUND IN ALL THE FEMALES.

\begin{tabular}{|c|c|c|c|c|}
\hline \multirow{2}{*}{$\begin{array}{c}\text { No. of } H C G \\
\text { injections }\end{array}$} & \multirow{2}{*}{$\begin{array}{l}\text { No. of } \\
\text { females } \\
\text { paired }\end{array}$} & \multirow{2}{*}{$\begin{array}{l}\text { No. pregnant at } \\
17 \frac{1}{2} \text { days post } \\
\text { coitum }\end{array}$} & \multicolumn{2}{|c|}{$\begin{array}{c}\text { Mean No. of embryos } \\
\text { pregnant female } \\
\pm \text { S.E. }\end{array}$} \\
\hline & & & Live & Total \\
\hline $\begin{array}{r}0 \\
1 \\
6 \\
12 \\
18 \\
24\end{array}$ & $\begin{array}{r}10 \\
6 \\
5 \\
5 \\
5 \\
5\end{array}$ & $\begin{array}{r}10 \\
6 \\
4 \\
5 \\
5 \\
5\end{array}$ & $\begin{array}{r}11.5 \pm 1.1 \\
11.7 \pm 1.4 \\
12.0 \pm 1.7 \\
13.4 \pm 1.5 \\
9.4 \pm 1.5 \\
10.4 \pm 1.5\end{array}$ & $\begin{array}{r}13 \cdot 0 \pm 1 \cdot 0 \\
13 \cdot 0 \pm 1 \cdot 3 \\
12 \cdot 6 \pm 1 \cdot 6 \\
13.6 \pm 1 \cdot 4 \\
9.6 \pm 1 \cdot 4 \\
12.4 \pm 1.4\end{array}$ \\
\hline
\end{tabular}

Number of eggs shed and fertilized at natural oestrus

It is clear from Tables 2 and 3 that, when the HCG injections were stopped and the females paired with males, the number of eggs shed at the next natural oestrus, and the number of embryos successfully maintained in the ensuing pregnancies, were affected little if at all by the previous HCG treatment. 
Interval between pairing and mating

The distribution of intervals in the various groups is shown in Table 4 . In the females which had received no HCG, $75 \%$ of the plugs were found on the 3rd day after mating. In the females receiving one or six HCG injections, this pattern was upset, and the mean interval increased from less than 3 to more than 6 days.

TABLE 4

THE NUMBER OF FEMALES THAT MATED ON SUCCESSIVE DAYS FOLLOWING DIFFERENT DURATIONS OF TREATMENT WITH HGG

\begin{tabular}{c|cccccccccc|c}
\hline \multirow{2}{*}{$\begin{array}{c}\text { No. of HCG } \\
\text { injections }\end{array}$} & $\mathbf{1}$ & 2 & 3 & 4 & 5 & 6 & 7 & 8 & 9 & 11 & Total No. of \\
females paired \\
\hline 0 & 2 & 2 & 15 & 1 & - & - & - & - & - & - & 20 \\
1 & - & - & 1 & 1 & - & 1 & 1 & 1 & 1 & - & 6 \\
6 & - & - & 1 & 2 & 3 & 1 & - & - & 2 & 1 & 10 \\
12 & - & 1 & 8 & - & 1 & - & - & - & - & - & 10 \\
18 & 2 & 4 & 3 & - & - & - & - & - & - & 1 & 10 \\
24 & 1 & 3 & 5 & - & - & - & - & - & - & 1 & 10 \\
\hline
\end{tabular}

With twelve or more injections, the interval again shortened. The 11-day intervals probably indicate that the females had become pseudopregnant, as 11 days is the modal duration of pseudopregnancy in Q-strain females (McLaren, unpublished).

Females receiving HCG daily for more than 24 days

Eighteen females were still receiving daily injections of HCG after the 24th day of the experiment. Vaginal smears were taken from these on three successive days; all the females appeared to be undergoing normal oestrous cycles in spite of the HCG treatment. Two females were killed on the morning of oestrus; each had shed ten eggs.

Five females were used to see whether any response to higher doses of HCG could be elicited. One received 2 i.u., one 4 i.u., two 8 i.u. and one 16 i.u. of HCG. None had shed any 'fresh' eggs the following morning, though the females given 2 i.u. and 16 i.u. each contained some 'old' eggs.

No significant deviation from normal was observed either in the number of eggs shed, or in the maintenance of pregnancy and number of embryos, in those females which were given daily injections of either distilled water or HCG throughout pregnancy.

\section{DISCUSSION}

After 6 days of daily HCG injections, our female mice were still responding at almost the initial level, and presumably had been doing so daily since the start of the experiment, but after 12 days they had ceased to ovulate in response to the treatment (Table 1). In the later stages of the experiment, it became clear that the exogenous hormone was now quite without effect: the females were undergoing normal oestrous cycles, and did not respond even to greatly increased doses of HCG. 
In those females in which natural oestrus was detected, either by vaginal smears or, in paired females, by the presence of a copulation plug, the number of eggs shed was within the normal range, even when HCG treatment was continued up to the time of killing. Almost certainly, therefore, the unresponsiveness was due not to induced refractoriness of the ovary or to the exhaustion of the supply of available follicles, but was an immunological phenomenon. The immune reaction was evidently directed against the antigenically foreign material only, and not against endogenous luteinizing hormone ( $\mathbf{L H})$.

The peak of mating on the third night after the untreated females had been paired with males indicates a male-induced synchronization of oestrus as reported by Whitten (1959). This effect is strongly marked in Q-strain females and is routinely used in this laboratory to synchronize oestrus. During the period when the female mice were responding to HGG (the 1-and 6-day groups), the synchronization vanished, and the interval between the time of pairing and mating was more than doubled (Table 4). Once the response to HCG had ceased, however, the synchrony reappeared, indicating that the females were now 'ignoring' the HCG treatment.

Lin \& Bailey (1965) observed that follicular development continued during repeated sequential treatment with PMS and HCG, and that pairing with males was followed by mating, and ovulation of the natural number of eggs. From this, they concluded that immunity must be primarily elicited against HCG. Their argument, however, assumes that immunity to PMs would also operate against endogenous FSH, and similarly that there is considerable immunological cross-reaction between HGG and endogenous LH. These assumptions are not supported either by the observation of Greenwald (1963) that 'anti-PMs antiserum' does not react against guinea-pig FSH, or by our indication that immunity to HGG does not affect murine LH. With gonadotrophins of pituitary rather than uterine origin, on the other hand, the older literature (e.g. Rowlands, 1937) indicates that there are considerable antigenic cross-reactions between species.

As Lin and Bailey do not give any information about the behaviour of their anovulatory females in terms of the oestrous cycle, the time between pairing with males and mating, or the proportion of the females which ovulated, it is difficult to compare their results with ours. Possibly their anovulatory females could be compared to our 12-day group, so that if treatment had been continued their females might have started to ovulate naturally, regardless of the gonadotrophin treatment.

Because of the immunity which developed, our initial aim, which was to see for how long the ovary was capable of maturing and shedding a fresh crop of eggs daily, was not fulfilled. The immunological obstacle could in principle be overcome, either by inducing tolerance to HCG, or by using LH of mouse rather than of human origin. The second procedure, however, would not necessarily provide a satisfactory solution: in the case of human growth hormone repeatedly administered to human pituitary dwarfs, the effect on growth may be suppressed by the development of specific antibodies (Prader, Illig, Szeky \& Wagner, 1964). This suggests that the immune response can be directed against individualor hormone-specific as well as species-specific antigens. 


\section{ACKNOWLEDGMENTS}

We would like to express our gratitude to Phyllis Black for her competent technical assistance, and to the Ford Foundation for financial support.

\section{REFERENCES}

Edwards, R. G. \& Fowler, R. E. (1960) Superovulation treatment of adult mice; their subsequent natural fertility and response to further treatment. 7. Endocr. 21, 147.

Greenwald, G. S. (1963) Effect of anti-PMS on superovulation in the hamster. Endocrinology, 73, 436. LAND, R. B. (1965) A genetic study of fertility in the mouse. Ph.D. thesis, University of Edinburgh.

LiN, T. P. \& BAILEY, D. W. (1965) Difference between two inbred strains of mice in ovulatory response to repeated administration of gonadotrophins. 7. Reprod. Fert. 10, 253.

Prader, A., Illig, R., Szeky, J. \& Wagner, H. (1964) The effect of human growth hormone in hypopituitary dwarfism. Archs Dis. Childh. 39, 535.

Rowlands, I. W. (1937) The effect of anti-gonadotrophic serum on the reproductive organs of the normal animal. Proc. R. Soc. B, $121,517$.

Thompson, K. W. (1941) Antihormones. Physiol, Rev. 21, 588.

Whitten, W. K. (1959) Occurrence of anoestrus in mice caged in groups. F. Endocr. 18, 102.

Willett, E. L., Buckner, P. J. \& MaShan, W. H. (1953) Refractoriness of cows repeatedly superovulated with gonadotrophins. 7. Dairy Sci. 36, 1083. 